\title{
Synthesis and anti-acetylcholinesterase activity of benzotriazinone-triazole systems
}

\author{
SETAREH MOGHIMI ${ }^{\mathrm{a}}$, FERESHTEH GOLI-GARMROODI ${ }^{\mathrm{a}}$, HEDIEH PILALI $^{\mathrm{a}}$, \\ MOHAMMAD MAHDAVI ${ }^{\mathrm{b}}$, LOGHMAN FIROOZPOUR $^{\mathrm{b}}$, HAMID NADRI $^{\mathrm{c}}$, \\ ALIREZA MORADI $^{\mathrm{c}}$, ALI ASADIPOUR $^{\mathrm{d}}$, ABBAS SHAFIEE $^{\mathrm{a}}$ and ALIREZA FOROUMADI ${ }^{\mathrm{a}, \mathrm{d}, *}$ \\ ${ }^{a}$ Department of Medicinal Chemistry, Faculty of Pharmacy and Pharmaceutical Sciences Research Center, \\ Tehran University of Medical Sciences, Tehran, Iran \\ ${ }^{b}$ Drug Design and Development Research Center, Tehran University of Medical Sciences, Tehran, Iran \\ ${ }^{\mathrm{c}}$ Department of Medicinal Chemistry, Faculty of Pharmacy, Shahid Sadoughi University of Medical Sciences, \\ Yazd, Iran \\ ${ }^{\mathrm{d}}$ Department of Medicinal Chemistry, Faculty of Pharmacy and Neuroscience Research Center, Institute of \\ Neuropharmacology, Kerman University of Medical Sciences, Kerman, Iran \\ e-mail: aforoumadi@yahoo.com
}

MS received 15 March 2016; revised 23 July 2016; accepted 28 July 2016

\begin{abstract}
An approach for the construction of benzotriazinone-triazole system is described. The synthesis is based on diazonium chemistry and subsequent intramolecular heteroatom-heteroatom bond formation. The introduction of triazole moiety occurred via click reaction catalyzed by nano-sized copper, supported on modified silica mesopore KIT-5 leading to the desired products in excellent yield. Also, in vitro acetylcholinesterase (AChE) inhibitory activities of the target compounds were screened by Ellman's method.
\end{abstract}

Keywords. Triazole; benzotriazinone; diazonium chemistry; nanocatalyst; acetylcholinesterase.

\section{Introduction}

Nitrogen-containing heterocycles are key structural motifs in natural and synthetic bioactive agents. ${ }^{1}$ In the library of six-membered heterocyclic frameworks, 1,2, 3-benzotriazines which show exceptional bioactivity are widely used in medicinal chemistry. In the benzotriazine class of compounds, 1,2,3-benzotriazine-4-one ${ }^{2}$ is recognized as a core structure in molecules exhibiting various biological effects including antiarthritic, ${ }^{3}$ anesthetic, ${ }^{4}$ diuretic, ${ }^{5}$ sedative, ${ }^{6}$ antitumor, ${ }^{7}$ and chorismate inhibitory activities. ${ }^{8}$ The sustained interest in triazine chemistry was not restricted to the application of these compounds in pharmaceuticals and other bioactive molecules. There are also some reports relying on their application as a substrate, from which a wide variety of new heterocyclic frameworks could be derived. ${ }^{9}$

Considered as a unique class of five-membered N-heterocycles, triazoles are mainly synthesized via the rapid and potent pathway, copper-catalyzed azide-alkyne cylcoaddition (CuAAC). ${ }^{10}$ Due to the importance of triazoles in diverse applied sciences, ${ }^{11}$ this reaction has

\footnotetext{
*For correspondence
}

become one of the well-studied reactions in modern organic chemistry, ${ }^{12}$ The pharmacological properties which are depicted in triazole-containing molecules ${ }^{13}$ could be attributed to the stereochemical features and the ability of this core in mimicking special bonds, resulting in anti-allergic, ${ }^{14}$ antibacterial ${ }^{15}$ and antiHIV $^{16}$ activities. Due to the remarkable features of benzotriazinone and triazole ring systems, we decided to synthesize new benzotriazinones-triazoles hybrid heterocycles.

Nanocatalysts have attracted interests in several catalytic organic reactions ${ }^{17}$ and in the synthesis of novel heterocyclic cores. ${ }^{18}$ Meanwhile, nanocatalysts especially those which are immobilized onto various supports, are considered as a big achievement in the sustainable construction of triazoles. ${ }^{19}$ As a result, we decided to introduce nanoparticles copper iodide/ APTES-KIT-5 (CuI-AK) in water ${ }^{20}$ as a catalyst for the synthesis of 3-(substituted-1,2,3-triazol-4-yl methyl)benzo $[d][1,2,3]$ triazin-4(3H)-ones, whereby we could meet global concerns about environmental issues along with the high yielding synthesis of new compounds which were not reported before.

Herein, we report our investigation on the synthesis of benzotriazinone-triazole system utilizing nano copper catalyst in water. The reaction proceeded by 
only three-steps and produced 3-(substituted-1H-1,2,3triazol-4-yl methyl)benzo[ $d][1,2,3]$ triazin-4(3H)-ones in overall high yield.

\section{Experimental}

\subsection{Materials and Methods}

Melting points were taken on a Kofler hot-stage apparatus and are uncorrected. ${ }^{1} \mathrm{H}$ and ${ }^{13} \mathrm{C}$ NMR spectra were recorded on a Bruker FT-500, using tetramethylsilane (TMS) as an internal standard. The infrared (IR) spectra were obtained on a Nicolet Magna FT-IR 550 spectrophotometer ( $\mathrm{KBr}$ disks). Mass spectra were recorded on an Agilent Technology (HP) mass spectrometer operating at an ionization potential of $70 \mathrm{eV}$. Elemental analysis were carried out with a Perkin-Elmer model 240-C apparatus.

2.1a Biological activity assay: Colorimetric Ellman's method ${ }^{21}$ was used to evaluate the inhibitory potency of target compounds toward AChE. Acetylcholinesterase (AChE, E.C. 3.1.1.7, Type V-S, lyophilized powder, from Electric eel, 1000 unit) was obtained from Sigma-Aldrich. 5, 5'-Dithiobis(2-nitrobenzoic acid) (DTNB), potassium dihydrogen phosphate, dipotassium hydrogen phosphate, potassium hydroxide, sodium hydrogen carbonate, and acetylthiocholine iodide were purchased from Fluka. Donepezil hydrochloride was obtained from Merck, Darmstadt,
Germany. In short, to determine $\mathrm{IC}_{50}$ values, $50 \mu \mathrm{L}$ of the five different concentration of the test compounds that produced inhibition in the range of $20-80 \%$ was added to the mixture of $3 \mathrm{~mL}$ phosphate buffer 0.1 $\mathrm{M}, \mathrm{pH}=8.0$ and $100 \mu \mathrm{L}$ of DTNB solution $(0.1 \mathrm{M})$ and $50 \mu \mathrm{L}$ AChE. $10 \mu \mathrm{L}$ solution of acetylthiocholine iodide $(0.15 \mathrm{M})$ as substrate was added following 10 min incubation at $25^{\circ} \mathrm{C}$. The progress curve was plotted by measuring the absorbance at $412 \mathrm{~nm}$ for $6 \mathrm{~min}$. The $\mathrm{IC}_{50}$ values were determined graphically from inhibition curves (inhibitor concentration vs percent of inhibition). UNICO double beam spectrophotometers 2100 was used for colorimetric measurements.

\subsection{Spectral data of some of the products}

2.2a 3-((1-Benzyl-1H-1,2,3-triazol-4-yl)methyl)benzo [d][1,2,3]triazin-4(3H)-one (5a): Pale yellow solid, [0.27 g, 86\%]; M.p. $176-178^{\circ} \mathrm{C}$; IR (KBr): 1678, 1456, 1331, 1059, 784, $694 \mathrm{~cm}^{-1} ;{ }^{1} \mathrm{H}$ NMR (500 MHz, DMSO- $\left.d_{6}\right): \delta 5.56(\mathrm{~s}, 2 \mathrm{H}), 5.64(\mathrm{~s}, 2 \mathrm{H}), 7.30(\mathrm{~d}$, $J=8.0 \mathrm{~Hz}, 1 \mathrm{H}), 7.32-7.37(\mathrm{~m}, 3 \mathrm{H}), 7.94(\mathrm{t}, J=7.3$ $\mathrm{Hz}, 1 \mathrm{H}), 8.09$ (t, $J=7.3 \mathrm{~Hz}, 1 \mathrm{H}), 8.16-8.18(\mathrm{~m}, 1 \mathrm{H})$, $8.19(\mathrm{~s}, 1 \mathrm{H}), 8.20(\mathrm{~d}, J=8.0 \mathrm{~Hz}, 1 \mathrm{H}), 8.25(\mathrm{~d}, J=8.0$ $\mathrm{Hz}, 1 \mathrm{H}) \mathrm{ppm} ;{ }^{13} \mathrm{C}$ NMR $\left(125 \mathrm{MHz}, \mathrm{DMSO}-d_{6}\right): \delta 44.6$, 52.8, 119.3, 123.9, 124.5, 127.9, 128.0, 128.5, 128.6, 133.0, 135.4, 135.8, 142.2, 143.6, 154.4 ppm; MS: $m / z$ $(\%)=318\left(51, \mathrm{M}^{+}\right), 227$ (29), $146(100), 91$ (22), 77 (39). Anal. Calcd. (\%) for $\mathrm{C}_{17} \mathrm{H}_{14} \mathrm{~N}_{6} \mathrm{O}: \mathrm{C}, 64.14 ; \mathrm{H}$, 4.43; N, 26.40. Found (\%): C, 64.21; H, 4.32; N, 26.51.

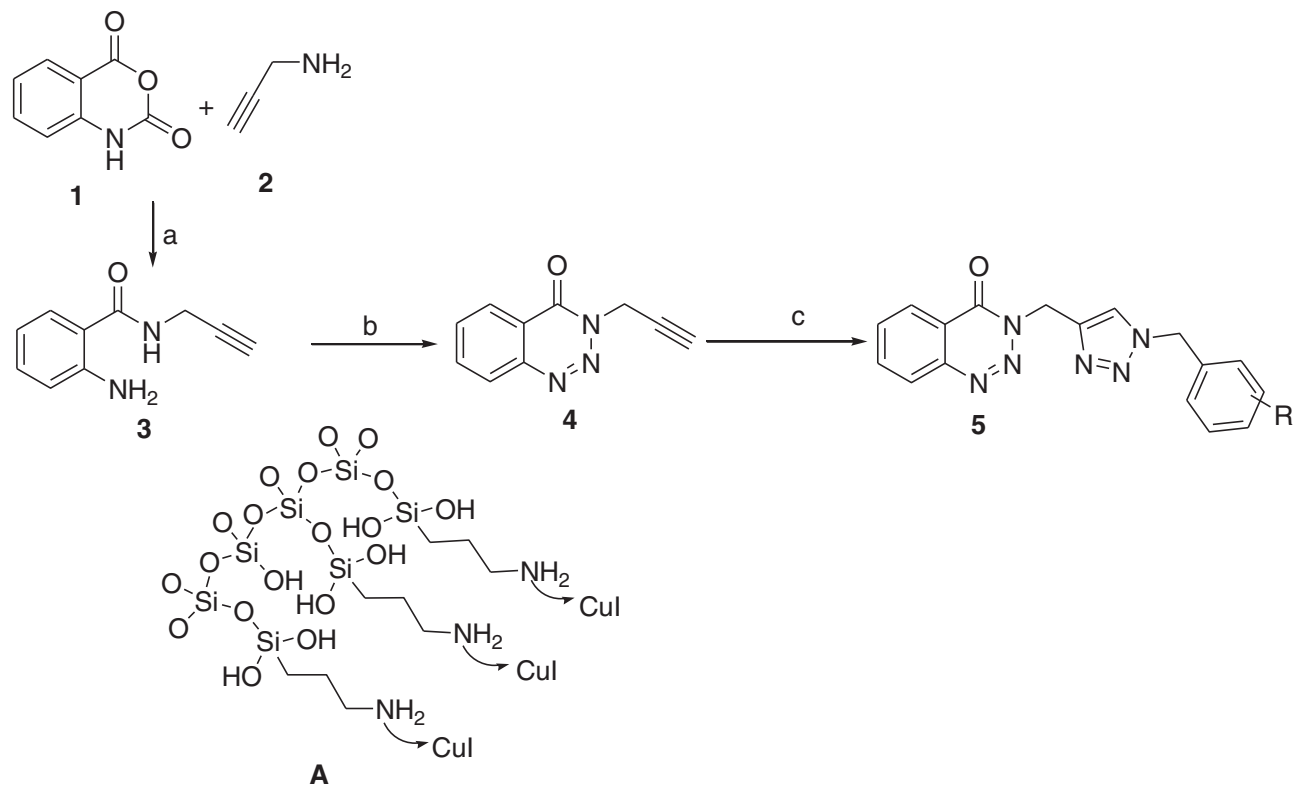

Scheme 1. Reagents and conditions: (a) $\mathrm{H}_{2} \mathrm{O}$, r.t.; (b) $\mathrm{NaNO}_{2}, \mathrm{HCl}$ (10\%), acetone; (c) $\mathrm{NaN}_{3}$, benzyl bromides, CuI-AK, $\mathrm{H}_{2} \mathrm{O}$, reflux. 


\section{Results and discussion}

\subsection{Synthesis and characterization}

Within our program for the synthesis of novel heterocycles, ${ }^{22}$ herein, we started by stirring isatoic anhydride and propargyl amine in water at room temperature to obtain pure 2-amino- $N$-(prop-2-yn1-yl)benzamide $\mathbf{3}$ as a white solid in $85 \%$ yield (Scheme 1). In the following step, exposure of 3 to acidic solution of sodium nitrite at $0^{\circ} \mathrm{C}$ for $1 \mathrm{~h}$, resulted in intramolecular nitrogen-nitrogen bond formation. In the final step, copper nanocatalyst on modified silicabased KIT-5 (CuI-AK), catalyst A was used. So, triple bond was subjected to click reaction in the presence of $\mathrm{NaN}_{3}$, different benzyl bromide derivatives and 0.04 $\mathrm{g}$ catalyst $\mathbf{A}$ in refluxing water. The desired products 5a-j were obtained after $3 \mathrm{~h}$ in good to excellent yields. Water rich solvents like $t-\mathrm{BuOH} / \mathrm{H}_{2} \mathrm{O}(1: 1.5)$ and $\mathrm{EtOH} / \mathrm{H}_{2} \mathrm{O}(1: 1.5)$ were also examined at reflux temperature for the synthesis of 5a which produced the desired product in same yields $(86 \%, 84 \%$, respectively). Nevertheless, we decided to report water as the reaction medium, in response to green chemistry principles.

To test the scope of the reaction, 10 different benzyl bromide derivatives were effectively examined to synthesize 5a-j in excellent yields (Table 1). In general, the presence of methyl substitution gave higher yields. Electron-withdrawing groups like $\mathrm{NO}_{2}, \mathrm{~F}, \mathrm{Cl}$, and $\mathrm{Br}$ also produced the desired products in good yields.

The $\mathrm{Cu}$ catalyst could be reused in click reaction, while significant loss of activity was observed in fifth run (Table 2).

Table 2. The recyclability of $\mathrm{Cu}$ nanoparticle in the formation of $\mathbf{5 a} .^{20}$

\begin{tabular}{lcc}
\hline Entry & Run & Yield (\%) \\
\hline 1 & 1 & 86 \\
2 & 2 & 85 \\
3 & 3 & 83 \\
4 & 4 & 82 \\
5 & 5 & 71 \\
\hline
\end{tabular}

a) Isolated yields.

Table 1. Substrate scope of 1,2,3-triazol-benzo[ $[d][1,2,3]$ triazin-4(3H)-ones.

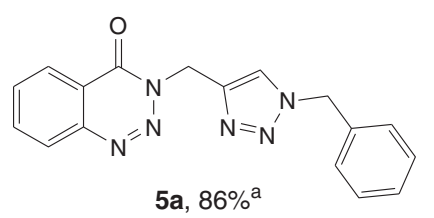<smiles>Cc1ccccc1Cn1cc(Cn2nnc3ccccc3c2=O)nn1</smiles><smiles>Cc1ccc(Cn2cc(Cn3nnc4ccccc4c3=O)nn2)cc1</smiles><smiles>CC(C)(C)C(C)(C)C</smiles><smiles>O=c1c2ccccc2nnn1Cc1cn(Cc2ccccc2Cl)nn1</smiles><smiles>O=c1c2ccccc2nnn1Cc1cn(Cc2cccc(Cl)c2)nn1</smiles><smiles>CC(C)(C)C(C)(C)C</smiles><smiles>O=c1c2ccccc2nnn1Cc1cn(Cc2ccc(Cl)c(Cl)c2)nn1</smiles><smiles>O=c1c2ccccc2nnn1Cc1cn(Cc2ccccc2Br)nn1</smiles><smiles>O=c1c2ccccc2nnn1Cc1cn(Cc2ccc([N+](=O)[O-])cc2)nn1</smiles>

${ }^{a}$ Isolated yields. 
Table 3. Acetylcholinesterase inhibitory activities of compounds $\mathbf{5 a}-\mathbf{5} \mathbf{j}{ }^{\text {a }}$

\begin{tabular}{lcc}
\hline Entry & Compound & $\mathrm{IC}_{50}(\mu \mathrm{M})$ \\
\hline 1 & $\mathbf{5 a}$ & $>25$ \\
2 & $\mathbf{5 b}$ & $1.88 \pm 0.091$ \\
3 & $\mathbf{5 c}$ & $>25$ \\
4 & $\mathbf{5 d}$ & $3.97 \pm 0.19$ \\
5 & $\mathbf{5 e}$ & $>25$ \\
6 & $\mathbf{5 f}$ & $>25$ \\
7 & $\mathbf{5 g}$ & $5.85 \pm 0.077$ \\
8 & $\mathbf{5 h}$ & $>25$ \\
9 & $\mathbf{5 i}$ & $>25$ \\
10 & $\mathbf{5 j}$ & $0.022 \pm 0.002$ \\
11 & Donepezil & \\
\hline
\end{tabular}

${ }^{\mathrm{a}}$ Data are expressed as Mean \pm SE (three independent experiments).

\subsection{Biological activity}

Acetylcholinesterase (AChE) is an important enzyme responsible for the hydrolysis of acetylcholine. The reduced amounts of this neurotransmitter is considered as the main reason for Alzheimer's disease. So, finding efficient acetylcholinesterase inhibitors alleviates global concerns and represents a promising treatment approach for this disease. As noted by Sharpless, AChE serves as a selective target for the construction of triazoles via click reaction which simultaneously act as an inhibitor for this enzyme. ${ }^{23}$ In addition, benzotriazinones are present in molecules with antiacetylcholinesterase activity. ${ }^{24}$ As our synthesized compounds contain both of these heterocyclic moieties, we decided to evaluate the activity of these compounds against acetylcholinesterase. Table 3 summarizes the anti-acetylcholinesterase activities of our products $\mathbf{5 a}-$ $\mathbf{5 j}$, determined by Ellman's method.

Unfortunately, only four compounds, $\mathbf{5 b}, \mathbf{5 d}, \mathbf{5 g}$ and $\mathbf{5 h}$, exhibited good inhibitory activities, albeit less than the reference drug, donepezil. It seems that the substituents have a profound effect on the activities in this order $2-\mathrm{Me}>2,3-d i \mathrm{Cl}_{2}>3-\mathrm{F}>3,4-d i \mathrm{Cl}_{2}$.

\section{Conclusions}

In conclusion, we have reported a versatile, mild and three-step strategy for the high yield synthesis of 3-(substituted-1 $H$-1,2,3-triazol-4-yl)methyl)benzo[d][1, 2,3 ]triazin-4(3H)-one derivatives. The click reaction which was the last step was carried out with the recently reported nano copper catalyst in water. Utilizing water as a solvent and reusability of the catalyst are the main advantages of this strategy in compliance with green chemistry principles.

\section{Supplementary Information (SI)}

Full experimental details and ${ }^{1} \mathrm{H},{ }^{13} \mathrm{C}$ NMR spectra are provided in the supplementary information available at www.ias.ac.in/chemsci.

\section{Acknowledgements}

This study was funded and supported by Research Council of Tehran University of Medical Sciences (TUMS); Grant no. 93-03-45-29092 and Iran National Science Foundation (INSF).

\section{References}

1. (a) Mitscher L A 2005 Chem. Rev. 105 559; (b) Estevez V N, Baelen G V, Lentferink B H, Vlaar T, Janssen E, Maes, B U W, Orru R V A and Ruijter E 2014 ACS Catal. 4 40; (c) Vlaar T, Cioc R C, Mampuys P, Maes B U W, Orru R V A and Ruijter E 2012 Angew. Chem., Int. Ed. 51 13058; (d) Ramachary D B, Kishor M and Babul Reddy G 2006 Org. Biomol. Chem. 4 1641; (e) Bakthadoss M and Murugan G 2010 Eur. J. Org. Chem. 5825; (f) Bakthadoss M, Sivakumar G and Kannan D 2009 Org. Lett. 11 4466; (g) Prakash R K and Nagarajan R 2015 Tetrahedron Lett. 56 69; (h) Ghosh S K and Nagarajan R 2014 RSC Adv. 420136

2. (a) Hunt J C A, Briggs E, Clarke E D and Whittingham W G 2007 Bioorg. Med. Chem. Lett. 17 5222; (b) Migawa M T and Townsend L B $2001 \mathrm{~J}$. Org. Chem. 66 4776; (c) Migawa M T, Drach J C and Townsend L B 2005 J. Med. Chem. 483840

3. Zandt $\mathrm{V}$ and Michael $\mathrm{C} 1997$ INHIBITION OF MATRIX METALLOPROTEASES BY SUBSTITUTED BIARYL OXOBUTYRIC ACIDS PCT Patent WO 9743239

4. Caliendo G, Fiorino F, Grieco P, Perissutti E, Santagada V, Meli R, Raso G M, Zanesco A and Nucci G D 1999 Eur. J. Med. Chem. 341043

5. Gadekar S M and Frederick J L 1962 J. Org. Chem. 27 1383

6. Gadekar S and Ross E 1961 J. Org. Chem. 26613

7. Rosowsky A 1993 2-AZA-2-DESAMINO ANALOGUES OF 5,8-DIDEAZAFOLIC ACID PCT Patent WO 9304051

8. Kumar K S, Adepu R, Sandra S, Rambabu D, Rama Krishna G, Malla Reddy C, Misra P and Pal M 2012 Bioorg. Med. Chem. Lett. 221146

9. (a) Miura T, Yamauchi M and Murakami M 2008 Org. Lett. 10 3085; (b) Hey D H, Ress C W and Todd A R 1968 J. Chem. Soc. C 1028; (c) Barker A J, Paterson T M, Smalley R K and Suschitzky H 1979 J. Chem. Soc. Perkin Trans. 12203 ; (d) Cirrincione G, Almerico A M, Dattolo G, Aiello E, Diana P and Mingoia F 1992 J. Heterocycl. Chem. 291309

10. (a) Kolb H C, Finn M G and Sharpless K B 2001 Angew. Chem. Int. Ed. 40 2004; (b) Hein J E and Fokin V V 2010 Chem. Soc. Rev. 391302

11. (a) Testa C, Scrima M, Grimaldi M, D’Ursi A M, Dirain M L, Lubin-Germain N, Singh A, Haskel-Luevano C, Chorev M M, Rovero P and Papini A M 2014 J. Med. 
Chem. 57 9424; (b) Agalave S G, Maujan S R and Pore V S 2011 Chem. Asian J. 6 2696; (c) Lau Y H, Rutledge P J, Watkinson M and Todd M H 2011 Chem. Soc. Rev. 40 2848; (d) Chu C and Liu R 2011 Chem. Soc. Rev. 40 2177; (e) Ramchander J, Rameshwar N, Sheshashena Reddy T, Raju G and Ram Reddy A 2014 J. Chem. Sci. 126 1063; (f) Tiwari V K, Mishra B B, Mishra K B, Mishra N, Singh A S and Chen X 2016 Chem. Rev. 116 3086

12. Liang L and Astruc D 2011 Coord. Chem. Rev. 2552933

13. Sahu J K, Ganguly S and Kaushik A 2013 Chin. J. Nat. Med. 11456

14. (a) Buckle D R and Rockell C J M 1982 J. Chem. Soc. Perkin Trans. 1 627; (b) Buckle D R, Outred D J, Rockell C J M, Smith H and Spicer B A 1983 J. Med. Chem. 26251

15. Genin M J, Allwine D A, Anderson D J, Barbachyn M R, Emmert D E, Garmon S A, Graber D R, Grega K C, Hester J B, Hutchinson D K, Morris J R J, Ford C W, Zurenko F G E, Hamel J C, Schaadt R D, Stapert D and Yagi B H 2000 J. Med. Chem. 43953

16. Alvarez R, Velazquez S, San-Felix A, Aquaro S, De Clercq E, Perno C F, Karlsson A, Balzarini J and Camarasa M J 1994 J. Med. Chem. 374185

17. Ananthan S A, Suresh R, Giribabu K and Narayanan V 2013 J. Chem. Sci. 1251365

18. (a) Mohsenimehr M, Mamaghani M, Shirini F, Sheikhan M, Abbaspour S and Sabet S L 2015 J. Chem. Sci. 127 1895; (b) Ghavami M, Koohi M and Kassaee M Z 2013 J. Chem. Sci. 1251347

19. (a) Beneteau V, Olmos A, Boningari T, Sommer J and Pale P 2010 Tetrahedron Lett. 51 3673; (b) Orgueira $\mathrm{H}$ A, Fokas D, Isome Y, Chan P C -M and Baldino C M 2005 Tetrahedron Lett. 46 2911; (c) Alonso F, Moglie Y and Radivoy G 2015 Acc. Chem. Res. 482516
20. Mirsafaei R, Heravi M M, Ahmadi S, Moslemin M H and Hosseinnejad T 2015 J. Mol. Catal. A: Chem. 402 100

21. Ellman G L, Courtney K D, Andres V J and Feather-Stone R M 1961 Biochem. Pharmacol. 788

22. (a) Sadat-Ebrahimi S E, Zarj M G, Moghimi S, Yahya-Meymandi A, Mahdavi M, Arab S, Shafiee A and Foroumadi A 2015 Synth. Commun. 45 2142; (b) Farzipour S, Saeedi M, Mahdavi M, Yavari H, Mirzahekmati M, Ghaemi N, Foroumadi A and Shafiee A 2014 Synth. Commun. 44 481; (c) Pilali H, Faraji Kamazani S, Moradi S, Moghimi S, Mahdavi M, Firoozpour L, Shafiee A and Foroumadi A 2016 Synth. Commun. 46 563; (d) Farjadmand F, Arshadi H, Moghimi S, Nadri H, Moradi A, Eghtedari M, Jafarpour F, Mahdavi M, Shafiee A and Foroumadi A 2016 J. Chem. Res. 40 188; (e) Mahdavi M, Estabragh R F, Moghimi S, Sayahi M H, Shafiee A and Foroumadi A 2016 Synlett 27 1359; (f) Sadat-Ebrahimi S E, Irannezhad S, Moghimi S, Yahya-Meymandi A, Mahdavi M, Shafiee A and Foroumadi A 2015 J. Chem. Res. 39 495; (g) Noushini S, Mahdavi M, Firoozpour L, Moghimi S, Shafiee A and Foroumadi A 2015 Tetrahedron 716272

23. (a) Zhu X L, Yu N X, Hao G F, Yang W C and Yang G F 2013 J. Mol. Graph. Model. 41 55; (b) Lewis W G, Green L G, Grynszpan F, Radic Z, Carlier P R, Taylor P, Finn M G and Sharpless K B 2002 Angew. Chem. Int. Ed. 41 1053; (c) Senapati S, Cheng Y and McCammon J A 2006 J. Med. Chem. 49 6222; (d) Bourne Y, Sharpless K B, Taylor P and Marchot P 2016 J. Am. Chem. Soc. 1381611

24. Catto M, Berezin A A, Lo Re D, Loizou G, Demetriades M, De Stradis A, Campagna F, Koutentis P A and Carotti A 2012 Eur. J. Med. Chem. 5884 